\title{
Tramped Teats - Clinical Mastitis Disease Complex in Tied Cows. Environmental Risk Factors and Interrelationships with Other Diseases
}

\author{
By P. A. Oltenacu, P. H. Bendixen, B. Vilson and I. Ekesbo \\ Depàrtment of Animal Science, College of Agriculture and Life Sciences, \\ Cornell University, Ithaca, NY, USA, and Faculty of Veterinary Medicine, \\ Swedish University of Agricultural Sciences, Skara, Sweden.
}

\begin{abstract}
Oltenacu, P. A., P. H. Bendixen, B. Vilson and I. Ekesbo: Tramped reats clinical mastitis disease complex in tied cows. Environmental risk factors and interrelationships with other diseases. Acta vet. scand. 1990, 31, 471-478. - The effects of stall length, manure system, type of bedding and calving disorders on incidence rates of tramped teats, udder injuries, and clinical mastitis in Swedish Red and White tied cows, as well as interrelationships between these 3 disorders were investigated. Data used consisted of 370 herds, for a total of 45,133 cow records.

Cows in herds with liquid manure system were at hihger risk of udder injuries and mastitis than in herds with solid system. Lower risk of both udder injuries and mastitis was found for cows in herds with short stall size $(<180 \mathrm{~cm})$ compared to herds with stalls of $205-219 \mathrm{~cm}$ length. It was suggested that other factors, such as slipperiness of the stall floor and presence and type of feeding barrier, must be considered when the effect of stall characteristics on tramped teats is investigated. In farms with solid manure system cut straw or sawdust bedding increased the risk of tramped teats and mastitis relative to uncut straw. Parity and calving disorders were important risk factors for udder health and their effect was greater in herds with liquid manure system. Tramped teats and udder injuries were the most serious risk factors for clinical mastitis.
\end{abstract}

udder injuries; epidemiology; udder health.

\section{Introduction}

Mastitis is one of the most common diseases affecting dairy cattle. In addition to high prevalence, mastitis is a costly disease, causing significant economic losses to the dairy farmers. In Sweden the loss per mastitic cow has been estimated at 780 Swedish crowns (SEK) in 1973. Emanuelson (1987) estimated these losses at 2,210 SEK per cow and about 800 million SEK on the national basis in 1985.

Quantitative knowledge with respect to the effect of all potential risk factors associated with clinical mastitis is needed in order to improve farmer's ability to control this disease and minimise economic losses.

Bakken (1982) reported that $26 \%$ of the variation in subclinical mastitis could be explained by variation in the environment. Ekesbo (1966), Grommers et al. (1972) and Karlsson \& Gustafsson (1977) have shown that environmental factors such as stall length, amount and type of bedding used, construction of the feed barrier and other factors play an important role with respect to udder health. The increase in risk of mastitis with age was shown by Bunch et al. (1984), Dohoo et al. (1984) and Saloniemi 
(1980). The association of clinical mastitis with teat injuries was reported by Ekesbo (1966), Pearson \& Mackie (1979) and Sieber \& Farnsworth (1981), with veterinary assisted dystocia and retained placenta by $\mathrm{Ol}$ tenacu et al. (1989), with milk fever by Curtis et al. (1985), and with ketosis by Dohoo \& Martin (1984).

The objectives of this study were: a) to evaluate the role of 3 environmental factors (stall size, bedding material, and manure system) on the incidence rate of tramped teats, udder injuries, and clinical mastitis in the first 3 months postpartum; and b) to investigate the interrelationships among several diseases in the first 3 months post partum, with special emphasis on the effect of parturition related disorders (dystocia, retained placenta, milk fever) on tramped teats - udder injuries - clinical mastitis complex, and on the interrelationships among these 3 udder disorders.

\section{Materials and methods}

This study was conducted using a data bank from the Department of Animal Hygiene, Faculty of Veterinary Medicine, Swedish University of Agricultural Sciences, Skara, Sweden, which contains detailed information on diseases and production of individual cows, as well as on herd environmental factors and management practices. Data used was collected during the period October 1970 to September 1974 as a descriptive epidemiological project for the purpose of identifying risk factors. Description of the population studied, the procedure used for selecting herds, data collection, storage and validation are described in Bendixen et al. (1986).

The following diseases were considered: dystocia, retained placenta, milk fever, tramped teats, udder injuries, and mastitis. Birth of single or multiple calves was also considered. The definitions of these diseases are presented in Bendixen et al. (1986). The study was restricted to the first 3 months after parturition which represents a period of higher risk for many of these diseases.

The population of herds selected for the study consisted of all herds with 20 or more cows in a tied system and for which information was available in the data bank for 3 or more consecutive years. The following environmental factors were evaluated: stall lengths, with length of 205-219 cm, 180 $204 \mathrm{~cm}$ and $<180 \mathrm{~cm}$ considered; types of bedding material, with uncut straw, cut straw, and sawdust considered; and manure systems, with solid and liquid manure systems considered. The final data set consisted of 370 herds for a total of 45,133 cow records for Swedish Red and White breed.

Linear logistic regression models were used to evaluate the effects of environmental factors, parity, and prior exposure to other diseases (single or multiple calves, dystocia, milk fever, retained placenta) or incidence of tramped teats, udder injuries and mastitis. The effect of prior or simultaneous occurrence of tramped teats and udder injuries on mastitis was also evaluated.

The logistic model used in the main analysis was:

$\operatorname{Ln}(\mathrm{p} / 1-\mathrm{p})=\mathrm{B}_{0}+\mathrm{B}_{1 \mathrm{j}} \mathrm{STL}_{\mathrm{ji}}+\mathrm{B}_{2 \mathrm{k}} \mathrm{BDG}_{\mathrm{ki}}$

$+\mathrm{B}_{3} \mathrm{MNR}_{\mathrm{i}}+\mathrm{B}_{41} \mathrm{LCT}_{\mathrm{li}}+\mathrm{B}_{5 \mathrm{~d}} \mathrm{DIS}_{\mathrm{di}}+\mathrm{e}_{\mathrm{i}}$

where:

$\operatorname{Ln}(p / 1-p)$ is the natural logarithm of the odds;

$\mathrm{STL}_{\mathrm{j}}$ is stall length, with $\mathrm{j}$ representing $180-204 \mathrm{~cm}$ or $<180 \mathrm{~cm}$ length, both relative to $205-219 \mathrm{~cm}$ length as base;

$\mathrm{BDG}_{\mathrm{k}}$ is bedding type, with $\mathrm{k}$ representing cut straw or sawdust, both relative to uncut straw as base; 
MNR is manure system, representing the liquid manure system relative to solid system as base;

$\mathrm{LCT}_{1}$ represents the parity, with $1=2,3,4$ for parity 2, 3, and 4 or greater, all relative to parity 1 as base;

DIS $_{d}$ represents exposure to prior diseases, with $\mathrm{d}$ being 4 or 6 diseases, depending on the variable being analysed;

$\mathrm{e}_{\mathrm{i}} \quad$ is the random error term;

B's are logistic regression coefficients.

With this model the effect of any of the considered factors on the incidence rate of a disease is adjusted for the effect of all other factors included in the model. In addition, the regression coefficients have a direct epidemiological interpretation and are easily converted into conditional odds ratios (OR). The manure system by stall length interaction was tested for statistical significance. The interaction of manure system with bedding type could not be assessed because of the confounding of these 2 factors present in the data. Therefore a separate analysis for each manure system was also performed with only the appropriate bedding types included in each model.

\section{Results and discussion}

The distribution of the 370 herds with tied cows included in the study by stall size, type of bedding and manure system is shown in Table 1. From all herds, $25.9 \%, 46.8 \%$, and $27.3 \%$ had stall sizes of length $<180$ $\mathrm{cm}, 180$ to $204 \mathrm{~cm}$, and 205 to $220 \mathrm{~cm}$; respectively. With respect to types of bedding used, $21.9 \%, 16.5 \%$, and $61.6 \%$ of the farms used uncut straw, cut straw, and sawdust, other materials, or no bedding, respectively. Regarding the manure system, $37.3 \%$ of the herds had liquid manure system and $62.7 \%$ had solid manure system. Note that only very few farms with liquid manure system used uncut or cut straw as bedding.

The cumulative incidence for the first 3 months of lactation per 100 cows was 2.5 , $6.0,6.9,4.5,1.4$ and 7.0 for dystocia, retained placenta, milk fever, tramped teats, udder injuries and clinical mastitis, respectively. It should be noted that $56.3 \%$, $46.0 \%$, and $66.2 \%$ of the total cases of tramped teats, udder injuries, and clinical mastitis (per lactation), occurred in the first 3 months after parturition.

Odds ratios for the risk factors considered, measuring the change in risk relative to the base population, were estimated for tramped teats, udder injuries, and clinical mastitis. In the main analysis all factors were considered and the estimated odds ratios are shown in Table 2.

Table 1. The distribution of farms in the data set by manure system, stall length, and bedding type.

\begin{tabular}{|c|c|c|c|c|c|c|c|}
\hline \multirow{2}{*}{$\begin{array}{l}\text { Bedding type: } \\
\text { Manure system: }\end{array}$} & \multicolumn{2}{|c|}{ Uncut straw } & \multicolumn{2}{|c|}{ Cut straw } & \multicolumn{2}{|c|}{ Sawdust } & \multirow[b]{2}{*}{ Total } \\
\hline & Solid & Liquid & Solid & Liquid & Solid & Liquid & \\
\hline \multicolumn{8}{|l|}{ Stall length: } \\
\hline Long & 25 & 0 & 27 & 0 & 37 & 12 & 101 \\
\hline Average & 39 & 0 & 23 & 2 & 53 & 56 & 173 \\
\hline Short & 15 & 2 & 5 & 4 & 8 & 62 & 96 \\
\hline Total & 79 & 2 & 55 & 6 & 98 & 130 & 370 \\
\hline
\end{tabular}


Table 2. Odds ratios associated with various risk factors for tramped teats, udder injuries, and clinical mastitis.

\begin{tabular}{llll}
\hline $\begin{array}{l}\text { Risk } \\
\text { factor }\end{array}$ & $\begin{array}{c}\text { Tramped } \\
\text { teats }\end{array}$ & $\begin{array}{l}\text { Udder } \\
\text { injury }\end{array}$ & $\begin{array}{l}\text { Clinical } \\
\text { mastitis }\end{array}$ \\
\hline $\begin{array}{l}\text { Manure system: } \\
\text { Liquid vs. solid }\end{array}$ & & & \\
$\begin{array}{l}\text { Stall length: } \\
\text { Average vs. long }\end{array}$ & 0.97 & $1.31^{*}$ & $1.17^{*}$ \\
Short vs. long & 1.10 & 0.84 & 0.98 \\
Bedding type: & 1.07 & $0.74^{*}$ & $0.83^{*}$ \\
Cut vs. uncut straw & & & \\
Sawdust vs. uncut straw & 1.14 & 0.89 & $1.30^{*}$ \\
Parity: & $1.35^{*}$ & 0.91 & $1.23^{*}$ \\
Lactation 2 vs. 1 & & & \\
Lactation 3 vs. 1 & $1.29^{*}$ & 0.93 & $1.32^{*}$ \\
Lactation > 3 vs. 1 & $1.98^{*}$ & 0.98 & $1.63^{*}$ \\
Disorders: & $2.57^{*}$ & $1.44^{*}$ & $2.33^{*}$ \\
Twins vs. single & & & \\
Dystocia yes vs. no & 1.24 & 1.08 & 1.10 \\
Milk fever yes vs. no & $1.57^{*}$ & $1.70^{*}$ & 1.08 \\
Ret. Placenta yes vs. no & 1.10 & 0.86 & $1.25^{*}$ \\
Tramped teats yes vs. no & 0.85 & 1.00 & $1.30^{*}$ \\
Udder injury yes vs. no & & & $6.15^{*}$ \\
\hline
\end{tabular}

* significantly different from $\mathrm{OR}=1$, with $\mathrm{p}<.05$.

Manure system

A significant association with udder health was present. It was found that the risk of udder injuries and of clinical mastitis was 1.3 and 1.2 times higher for cows in herds with liquid manure system than in herds with solid system. These results are in aggreement with Grommers et al. (1972), Karlsson \& Gustafsson (1977) and Bakken (1982), all reporting adverse effects associated with liquid manure systems on udder health.

Several authors, e.g. Ekesbo (1966), suggested that the use of little or no bedding, characteristic for liquid systems, could be responsible for the adverse effect of the system on udder helath. This hypothesis was addressed in the main analysis in which the effects associated with manure system were adjusted for the effects of bedding type. Under the assumption of no significant interaction, the results in Table 2 would suggest that the bedding type could not totally explain the adverse effect of liquid manure system on udder health and that other factors within the system may play a role. Subsequently, the role of the other risk factors with respect to udder health was evaluated separately for each manure system, with the odds ratios presented in Tables 3 and 4, respectively. The risk of udder health problems associated with both parity and occurance of prior disorders was higher in farms with liquid than in farms with solid manure system. 
Table 3. Odds ratios associated with various risk factors for tramped teats, udder injuries, and clinical mastitis. Data restricted to herds with solid manure system only.

\begin{tabular}{llll}
\hline $\begin{array}{l}\text { Risk } \\
\text { factor }\end{array}$ & $\begin{array}{c}\text { Tramped } \\
\text { teats }\end{array}$ & $\begin{array}{l}\text { Udder } \\
\text { injury }\end{array}$ & $\begin{array}{l}\text { Clinical } \\
\text { mastitis }\end{array}$ \\
\hline $\begin{array}{l}\text { Stall length: } \\
\text { Average vs. long }\end{array}$ & 1.07 & 0.81 & 0.98 \\
Short vs. long & 1.03 & $0.77^{*}$ & $0.86^{*}$ \\
Bedding type: & & & \\
Cut vs. uncut straw & 1.14 & 0.87 & $1.31^{*}$ \\
Sawdust vs. uncut straw & $1.32^{*}$ & 0.95 & $1.20^{*}$ \\
Parity: & & & \\
Lactation 2 vs. 1 & $1.23^{*}$ & 0.87 & $1.26^{*}$ \\
Lactation 3 vs. 1 & $1.97^{*}$ & 1.06 & $1.50^{*}$ \\
Lactation > 3 vs. 1 & $2.59^{*}$ & $1.41^{*}$ & $2.08^{*}$ \\
Disorders: & & & \\
Twins vs. single & 1.40 & 1.21 & 1.01 \\
Dystocia yes vs. no & $1.40^{*}$ & $1.69^{*}$ & 1.12 \\
Milk fever yes vs. no & 1.08 & 0.97 & $1.27^{*}$ \\
Ret. Placenta yes vs. no & 0.78 & 0.93 & $1.28^{*}$ \\
Tramped teats yes vs. no & & & $5.97^{*}$ \\
Udder injury yes vs. no & & & $3.08^{*}$ \\
\hline
\end{tabular}

* significantly different from $\mathrm{OR}=1$, with $\mathrm{p}<.05$.

Table 4. Odds ratios associated with various risk factors for tramped teats, udder injuries, and clinical mastitis. Data restricted to herds with liquid manure system and stalls with length $<180 \mathrm{~cm}$ (short stalls) only.

\begin{tabular}{llll}
\hline $\begin{array}{l}\text { Risk } \\
\text { factor }\end{array}$ & $\begin{array}{c}\text { Tramped } \\
\text { teats }\end{array}$ & $\begin{array}{l}\text { Udder } \\
\text { injury }\end{array}$ & $\begin{array}{l}\text { Clinical } \\
\text { mastitis }\end{array}$ \\
\hline $\begin{array}{l}\text { Bedding type: } \\
\text { None vs. sawdust }\end{array}$ & 0.76 & 0.92 & 1.24 \\
Parity: & & & \\
Lactation 2 vs. 1 & $1.65^{*}$ & 1.14 & $1.50^{*}$ \\
Lactation 3 vs. 1 & $1.96^{*}$ & 1.17 & $2.04^{*}$ \\
Lactation > 3 vs. 1 & $2.26^{*}$ & $1.35^{*}$ & $2.89^{*}$ \\
Disorders: & & & \\
Twins vs. single & 1.35 & 2.05 & 1.25 \\
Dystocia yes vs. no & $2.08^{*}$ & $3.26^{*}$ & 1.44 \\
Milk fever yes vs. no & 0.86 & 0.83 & $1.53^{*}$ \\
Ret. Placenta yes vs. no & 0.70 & 1.25 & $1.41^{*}$ \\
Tramped teats yes vs. no & & & $6.57^{*}$ \\
Udder injury yes vs. no & & & $1.85^{*}$ \\
\hline
\end{tabular}

* significantly different from $\mathrm{OR}=1$, with $\mathrm{p}<.05$. 


\section{Stall length}

The risk of udder injuries and mastitis, shown as odds ratios in Table 2, was 1.3 and 1.2 times lower for cows in farms with stall of length $<180 \mathrm{~cm}$ than for cows in farms with stalls of $205-219 \mathrm{~cm}$ lengths. These results, though unexpected, were not totally surprising as the published reports regarding the effect of stall size on udder health are somewhat conflicting. Grommers et al. (1972) found a relationship between width of the stall and mastitis but only if the depth of the udder was explicitly considered, Bakken (1982) found more clinical mastitis associated with wider stalls, Osterås \& Lund (1988) and Ekesbo (1966) found less mastitis in longer stalls, while Karlsson \& Gustafsson (1977) found no relationship between length or width of the stalls and the incidence of tramped teats. It is very likely that the relationships between stall characteristics and udder health traits are quite complex involving several other factors in addition to width and length of the stalls, such as slipperiness and type of stall floors, presence and type of feeding barrier, the presence of partitions, the depth of the gutter, etc. The description of stalls on the basis of length only, used in this study, was probably too simplistic to be appropriate for evaluating the relationship between stall characteristics and udder health. When these effects are studied, proper consideration should be given to all other factors which may be important. The manure system by stall length interaction was tested and found not significant.

\section{Bedding type}

The effect of 3 bedding types was evaluated in farms with solid manure system and the respective odds are shown in Table 3 . The risk of mastitis was greater for cows in farms using cut straw or sawdust, while for tramped teats the risk was greater among cows in farms using sawdust as bedding relative to farms using uncut straw. For liquid manure system the data was restricted to 62 farms with short stalls and the effect of sawdust versus no bedding on udder health was estimated (Table 4) and found statistically not significant.

These results are in accordance with Ekesbo (1966) and Karlsson \& Gustafsson (1977), both reporting better udder health associated with use of abundant straw bedding. Osterås \& Lund (1988) found the effect of bedding on udder health to be nonsignificant. In general very little bedding was used in the herds included in their study, which may have reduced the variation in udder health associated with bedding, leading to nonsignificance of the effect.

\section{Parity}

The results from main analysis, shown in Table 2, showed a significant increase in the risk of tramped teats, udder injuries and clinical mastitis with parity. The effect of parity on the risk of these diseases was also evaluated separately for cows in farms with solid and liquid manure systems and are shown in Tables 3 and 4 . For tramped teats and udder injuries the effect of parity was similar for both systems but a larger increase in risk of clinical mastitis with parity was found in farms with liquid manure system. These results are in agreement with Bakken (1982), Curtis et al. (1985), Dohoo et al. (1984), Pearson \& Mackie (1979), Saloniemi (1980), all indicating increased incidence of mastitis and/or other udder problems with age.

\section{Other disorders}

Several of the disorders occurring at calving were significant risk factors for udder health. Cows with dystocia had 1.6 and 1.7 higher risk of tramped teats and udder injuries than 
cows with normal parturition. Cows with milk fever or retained placenta had 1.3 times higher risk of developing clinical mastitis than cows free of the calving disorders considered in this study. When estimated separately for solid and liquid manure systems these interrelationships, shown in Tables 3 and 4 , were consistently higher for cows in farms with liquid manure system.

Increased risk of clinical mastitis among cows with dystocia or retained placenta was also reported by Dohoo \& Martin (1984) and Oltenacu et al. (1989). The most important risk factors for clinical mastitis were tramped teats and udder injuries which increased the risk of clinical mastitis 6.1 and 2.8 times, respectively. Similar relationship was also reported by Sieber \& Farnsworth (1981).

\section{References}

Bakken J: The relationship between environmental conditions and bovine udder diseases in Norwegian dairy herds. Acta Agric. Scand. 1982, 32, 23-31.

Bendixen PH, Vilson B, Ekesbo I, Astrand DB: Disease frequencies of tied zero-grazing dairy cows and of dairy cows on pasture during summer and tied during winter. Prev. Vet. Med. 1986, 4, 291-306.

Bunch KJ, Heneghan DJS, Hibbit KG, Rowlands $G J$ : Genetic influences of clinical mastitis and its relationship with milk yield, season, and stage of lactation. Livestock Prod. Sci. 1984, 11, 91-104.

Curtis CR, Erb HN, Sniffen CJ, Smith RD, Kronfeld DS: Path analysis of dry period nutrition, postpartum metabolic and reproductive disorders, and mastitis in Holstein cows. J. Dairy Sci. 1985, 68, 2347-2360.

Dohoo IR, Martin SW, McMillan I, Kennedy BW: Diseases, production and culling in Holsteinfriesian cows. II. Age, season and sire effects. Prev. Vet. Med. 1984, 2, 655-670.

Dohoo IR, Martin SW: Diseases, production and culling in Holstein-Friesian cows. III. Diseases and production as determinants of diseases. Prev. Vet. Med. 1984, 2, 671-690.

Ekesbo I: Disease incidence in tied and lose housed dairy cattle. Acta Agric. Scand. 1966, Suppl. 15, p. 1-74.

Emanuelson $U$ : Genetic studies on the epidemiology of mastitis in dairy cattle. Rapport 73. Dept. of An. Breeding and Genetics. Swedish University of Agric. Sciences. Uppsala 1987, pp. 1-57.

Grommers FJ, van de Braak AE, Antonisse $H W$ : Direct trauma of the mammary glands in dairy cattle. II. Variations in incidence due to housing variables. Brit. vet. J. 1972, 128, 199205.

Karlsson M, Gustafsson B: Predisponerande faktorer for spenetramp. (Predisposing factors for tramped teats). Sven. Vet.-Tidn. 1977, 30, 367-372.

Osterås $O$, Lund A: Epidemiological analyses of the association between bovine udder health and housing. Prev. Vet. Med. 1986, 6, 79-90.

Oltenacu PA, Frick A, Lindhé B: Epidemiological study of several clinical diseases, reproductive performance and culling in primiparous Swedish cattle. Prev. Vet. Med. 1990, 9, 59-74.

Pearson JKS, Mackie DP: Factors associated with the occurrence, cause and outcome of clinical mastitis in dairy cattle. Vet. Rec. 1979, 105, 456-463.

Saloniemi $\mathrm{H}$ : Udder diseases in dairy cows-field observations on incidence, somatic cell and environmental factors and control. J. Sci. Agric. Soc. Finl. 1980, 52, 85-154.

Sieber RL, Farnsworth RJ: Prevalence of chronic teat-end lesions and their relationship to intramammary infection in 22 herds of dairy cattle. J. Amer. vet. med. Assoc. 1981, 178, 12631267.

\section{Sammanfattning}

Sjukdomskomplekset spentramp/klinisk mastit.

Riskfaktorer $i$ miljöen och samband med annan sjukdom hos bundna mjölkköer.

Inverkan av båslängd, gödselhanteringssystem och strömaterial studerades med avseende på incidensraten av spentramp, övriga juverskador och klinisk mastit under de 3 första månaderna efter partus hos 45133 SRB-kor i 370 besättningar. 
Riskutvärdering gjordes beträffande kalvningssjukdom (dystokia, retentio secundarium, och paresis puerperalis) samt tvillingfödslar eller ej gentemot spentramp-övriga juverskador-mastitkomplexet liksom beträffande förhållandet mellan dessa 3 senare lidanden.

Större risk för övriga juverskador resp. för mastit förelåg hos kor i besättningar med flytgödsel - än med fastgödselsystem.

I studien visade kor $\mathrm{i}$ besättningar med båslängd $<180 \mathrm{~cm}$ lägre risk för juverskador resp. mastit jämfört med kor på båslängderna 205-219 cm. Ingen signifikant skillnad förelåg beträffande spentrampsfrekvenser. Det är dock troligt att an- dra faktorer, som båspallsytans strävhet (halkighet), ev. närvaro av och typ av foderbordsavstängning, bör tas med i beräkningen när effekten av båslängd på juverhälsan utvärderas.

Användning av hackad halm eller sågspån som strö ökade risken för spentramp resp. mastit jämfört med ej hackad halm.

Ålder uttryckt i antal förlossningar ökade risken för spentramp och mastit.

Dystokia ökade risken för spentramp och övriga juverskador, medan paresis puerperalis och retentio secundarium ökade risken för mastit. Spentramp och övriga juverskador var de största riskfaktorerna för mastit.

(Received May 23, 1989; accepted December 7, 1989).

Reprints may be requested from: I. Ekesbo, Dept. of Animal Hygiene, Swedish University of Agricultural Sciences, P. O. Box 345, S-53200 Skara, Sweden. 